\title{
NOVA SODOBNA GROŽNJA NACIONALNI VARNOSTI - PRORAČUNSKA GROŽNJA
}

\section{NEW MODERN THREAT TO NATIONAL SECURITY - BUDGET THREAT}

Povzetek Težnja zmanjševanja vojaških izdatkov je značilna tudi za sodobno Slovenijo, čeprav se razsežnost in spekter groženj, ki nam grozijo, nista zmanjšala. Ravno nasprotno. Spremenile so se zgolj oblike teh groženj in pojavile nove, tako imenovane sodobne grožnje. Zmanjševanje vojaških izdatkov prinaša manjšo varnost državljanov in okrnjen nacionalni steber obrambe, kar se je pokazalo ob zadnji grožnji nacionalni varnosti, ob tako imenovani migrantski krizi, ko je na nepripravljenost Slovenske vojske in nizko stopnjo nacionalne varnosti opozoril celo vrhovni poveljnik obrambnih sil, predsednik države Borut Pahor. Poleg slabljenja domačega obrambnega sistema se je v zadnjih letih za nekatere grožnje nacionalni varnosti kot zelo šibka pokazala tudi pomoč evropskih institucij in Nata, zato je samozadostnost v nacionalnem varnostnem sistemu toliko bolj pomembna.

\section{Ključne Slovenska vojska, proračun, proračunska grožnja.}

besede

Abstract The tendency to reduce military expenditure is characteristic of the modern Slovenia as well, although the dimensions and the array of threats we face have not been reduced. Quite the opposite - they have merely changed their form and were joined by new, the so-called modern threats. The reduction of military expenditure contributes to the weaker security of the citizens and a stunted defence pillar, which proved to be the case in the recent threat to the national security, namely the migrant crisis. During that period, even the Commander-in-Chief, President Borut Pahor drew attention to the lack of readiness of the Slovenian Armed Forces and the low level of national security. In addition to the deteriorating Slovenian defence system, EU institutions and NATO have in the recent years also provided poor assistance with regard to certain threats to national security, which makes the self-sufficiency in the national security system all the more important.

Key words Slovenian Armed Forces, budget, budget threat. 
Uvod Če se zazremo v novejšo zgodovino ekonomske znanosti, lahko zatrdimo, da je o vzročni povezavi med varnostjo in ekonomijo razmišljal že znani ameriški ekonomist Paul Samuelson. V svojih prispevkih je izpostavil dilemo, ki je še vedno prisotna V našem vsakdanjem življenju, znano kot maslo ali topovi. Gre za pogled, ki na prvo mesto postavlja proizvodne zmogljivosti. Izbrana družba lahko proizvede več topov le, če zmanjša proizvodnjo masla. Seveda tu ne gre za neposreden prenos zamisli. Za današnji čas bi bilo primerno, da govorimo o produktih vojaškoindustrijskega kompleksa in produktih za splošno potrošnjo. Pri tem je pomembno upoštevati, da lahko družba z razvojem poveča proizvodne zmogljivosti, kar v končnem rezultatu pomeni več topov kot masla. Menim, da je Samuelsonova teorija svojo delno potrditev doživela med hladno vojno. Obe supersili sta krepili segment topov, a zmagala je stran, ki je ohranjala in z razvojem povečevala tudi segment masla, torej stran, ki je upoštevala tudi individualnost in človekove pravice posameznika.

Če dilemo maslo ali topovi prelijemo v slovensko stvarnost, lahko ugotovimo, da glavni mediji še vedno s pridom zlorabljajo to umetno ustvarjeno dilemo. Od hladne vojne potreb po topovih ni bilo več, zato se ta segment ni več krepil. A v Sloveniji je bilo drugače. Nestabilnost na Zahodnem Balkanu, zaradi katere je prišlo do krvave vojne in genocida ter postavljanja obrambnih sil na novih temeljih, je privedla do političnega soglasja o uresničitvi projektov temeljnih razvojnih programov. Medtem ko v Evropi po hladni vojni ni bilo več potrebe po krepitvi segmenta topov, ga je bila Slovenija prisiljena krepiti kljub embargu na uvoz orožja. Obenem smo se zavedali, da ne smemo pozabiti na preoblikovanje gospodarstva in iskanje novih trgov za svoje izvozno gospodarstvo. Menim, da smo se z vstopom v Nato navzeli prepričanja, da za našo varnost skrbi tako imenovani veliki brat. Naše zaveze smo vse manj izpolnjevali. Naši topovi so danes obrambni izdatki, maslo pa socialni transferji. Z nastopom krize leta 2008 so se določevalci zavestno odločili oslabiti izdatke za nacionalnovarnostni sistem, s posebnim poudarkom na obrambi. Praksa se je ohranila. Z nastopom novih varnostnih tveganj, med katere štejem tudi nedavno migrantsko krizo, se je izkazalo, da je potreba po topovih bistveno večja, kot smo predvidevali, in da je obramba $\mathrm{v}$ Republiki Sloveniji na zelo kritični točki. Predpogoj za varnost (topovi) so torej razpoložljiva finančna sredstva oziroma v Sloveniji javne finance, iz katerih se zagotavlja varnost državljanov. In varnost je pogoj za tuja vlaganja, delovanje izvozno naravnanih podjetij, logističnih sistemov in prometnih tokov ter povečanje turizma. Za razvoj in izboljšanje proizvodnih aktivnosti je nujna prav varnost.

\section{VARNOST, NACIONALNA VARNOST IN STEBRI OBRAMBE}

Varnost je ena izmed temeljnih človekovih potreb oziroma strukturnih prvin človekovega bivanja. Je temelj ustvarjalnosti, povezovanja, ustvarjanja in oblikovanja skupnega dobrega. Kot pravi Anžič, pa kljub pomembnosti varnost kot pojem in problem še vedno ni v celoti znanstveno obdelana. Deloma jo obravnavata sociološka in politološka znanost, vendar gre le za splošen in delni pristop. Z varnostnimi vprašanji in težavami, povezanimi z njimi, se skladno z zahtevami svojih disciplin ukvarjajo še psihologija, kriminalistika in kriminologija, posamezne 
pravne znanosti, obrambosolovje itn. V večini pristop ne temelji na vidikih sistemske teorije, ne glede na to, da so spoznanja o kompleksnosti varnosti že razmeroma dolgo znana (1997, str. 35).

Žnidarič je zapisal, da je varnost med drugim (tudi) javna dobrina, ki mora biti dostopna vsem, ne glede na to, ali si to želimo ali ne in ali se tega tudi vsakokrat polno zavedamo ali ne. Zagotavljanje varnosti je postalo $\mathrm{v}$ današnjih kulturnocivilizacijskih razmerah tržna kategorija - blago, ki ga stranke kupujejo pri zanj pristojnih podjetjih in agencijah. Posameznik se tega najprej zave na individualni ravni in v najožjem družinskem okolju. Šele z nadaljnjo socializacijo in prilagoditvijo priseljencev se dojemanje in razumevanje varnosti širita $\mathrm{v}$ obliki koncentričnih krogov od individualnih in nacionalnih vse do svetovnih razsežnosti. Varnost lahko razumemo tudi kot eno izmed eksistenčnih človekovih potreb, ki se intenzivneje izraža šele takrat, ko se človek znajde v kritičnih varnostnih okoliščinah. Bučar uvršča varnost kot dobrino posameznika takoj za fiziološkimi potrebami. Varnost je pogoj za razvoj kogar koli in česar koli. Brez nje ni pričakovati napredka, saj so že zdavnaj spoznali, da je med najpomembnejšimi vrednotami in omogoča uresničevanje večine drugih vrednot, zaradi česar jo problematizirajo prenekatere družbene znanosti, kot so pravo, sociologija, ekonomija in druge (2006, str. 53).

Varnost je torej vrednota, tako države kot družbe. Če so te vrednote ogrožene, kršene ali kako drugače diskreditirane, prihaja do pojavnih oblik, ki jih imenujemo varnostni pojav (Anžič, 1997, str. 36).

Varnostna dejavnost se danes izvaja prek varnostnega sistema, ki pomeni ustrezno stopnjo organiziranosti družbenih zmogljivosti za opravljanje varnostnih funkcij.

Slovenija je v Resoluciji oizhodiščih zasnove nacionalne varnosti Republike Slovenije iz leta 1993 nacionalno varnost opredelila kot stanje, v katerem so zagotovljeni uresničevanje človekovih pravic in temeljnih svoboščin, uravnotežen gospodarski razvoj ter uresničevanje drugih življenjskih interesov, delovanje demokratične, pravne in suverene ter ozemeljsko enotne in nedeljive države Republike Slovenije.

$\mathrm{Ob}$ vsem tem ne moremo mimo sodobnih varnostnih paradigem, ki premikajo mejo od tradicionalne nacionalne varnosti $\mathrm{k}$ varnosti posameznika, ki je postavljena v središče sodobnih varnostnih proučevanj. Tradicionalna nacionalna varnost govori o teritorialni integriteti in nacionalni neodvisnosti, sodobne paradigme pa o posameznikovi varnosti in individualni svobodi. Tradicionalne grožnje, kot so npr. vojaške grožnje in nasilje države, se pomikajo k netradicionalnim grožnjam sodobnega sveta. Sila kot sredstvo varnosti postaja sekundarni instrument, varnost kot taka pa postaja tržno blago, po katerem je veliko povpraševanja in ponudbe.

Brezovšek in Črnčec sta v svojem delu zapisala, da sodobna varnostna paradigma obravnava varnost $\mathrm{v}$ treh temeljnih konceptualnih okvirih, in sicer kot individualno, nacionalno in mednarodno varnost (2007). 
»Razvojni model sodobne družbe, ki temelji na predpostavki o možnostih neomejene gospodarske rasti, je povzročil zapleteno okoljsko, ekonomsko, socialno in etično krizo, ki jo človeštvo mora preseči, če se želi izogniti poglabljanju problemov, kot so podnebne spremembe, prekomerno izčrpavanje naravnih virov, dezertifikacija, deforestacija, erozija prsti in pomanjkanje vode, kar povzroča revščino, lakoto, okoljske migracije in konflikte.« (Malešič, 2012, str. 264)

V Republiki Sloveniji zagotavljanje nacionalne varnosti temelji na treh stebrih oziroma podsistemih, to so obrambni sistem, sistem notranje varnosti ter sistem varstva pred naravnimi in drugimi nesrečami.

\subsection{Obrambni sistem}

»Bistveni element nacionalne suverenosti je nedvomno ohranitev pravice do zagotovljene učinkovite obrambe.« (Rizman, 1998, str. 18) V razdelku 6.3 Resolucije o strategiji nacionalne varnosti Republike Slovenije iz leta 2010 je zapisano, da obrambni sistem Republike Slovenije predstavlja celoto političnih, normativnih, organizacijskih, vojaških, kadrovskih, materialnofinančnih, obveščevalno-varnostnih, informacijsko-komunikacijskih, razvojnoraziskovalnih, izobraževalnih in drugih dejavnosti, ki jih organizira država za učinkovito zagotavljanje obrambe.

Nosilka obrambnega sistema je Slovenska vojska. Poleg vojske so v njem še nevojaški deli, ki oblikujejo in uresničujejo obrambno politiko, zagotavljajo razmere za delovanje celotnega obrambnega sistema, nevojaške zmogljivosti za podporo Slovenski vojski in zavezniškim silam ter izvajajo priprave in ukrepe za obrambo države ter delovanje obrambnega sistema v kriznih razmerah (Resolucije o strategiji nacionalne varnosti Republike Slovenije iz leta 2010, 6.2).

Grizold je v svojem delu zapisal, da je glede na sprejete in usklajene dolgoročne načrte prestrukturiranja in razvoja zmogljivosti, vključno s posodabljanjem in modernizacijo vojske, temeljnega pomena zagotoviti njihovo redno uresničevanje, predvsem na organizacijskem, kadrovskem, materialnem in finančnem področju. Le tako naj bi se po njegovih besedah zagotovila ustrezna integracija slovenske vojske in celotnega obrambnega sistema v Natov sistem kolektivne obrambe in v obrambno organiziranost Evropske unije. Če bi bilo odstopanje zmogljivosti, ki so bile usklajene v Severnoatlantskem zavezništvu in Evropski uniji, bistveno, bi lahko bilo to za slovensko državo zelo škodljivo, saj bi se v tem primeru kot polnopravna članica obeh organizacij pokazala kot neverodostojna (2005, str. 178). Na to težavo je v svojem letnem poročilu za leto 2014 opozorilo tudi Ministrstvo za obrambo, ki je zapisalo, da bo nadaljevanje zmanjševanja števila pripadnikov Slovenske vojske negativno vplivalo na njeno delovanje doma in tudi na izpolnjevanje obveznosti Republike Slovenije do Nata (Letno poročilo Ministrstva za obrambo za leto 2014). 


\subsection{Sistem notranje varnosti}

V Resoluciji o strategiji nacionalne varnosti Republike Slovenije iz leta 2010 je zapisano, da sistem notranje varnosti predstavljajo institucionalni nosilci varnostnih nalog. V ta sistem so vključeni tudi pravosodni in drugi državni organi ter institucije, ki z uresničevanjem nalog prispevajo k notranji stabilnosti in varnosti. Grizold v svojem delu zapiše, da je načrtovanje razvoja civilne obrambe v Sloveniji v obdobju po letu 2004 izhajalo iz izhodišč, da je vojaška ogroženost manj verjetna in da je treba povečati varnost na novih (asimetričnih) virih ogrožanja, pri katerih so v ospredju nevarnost terorizma, širjenje orožja za množično uničevanje ter ranljivost komunikacijskih in informacijskih sistemov (2005, str. 149).

V Resoluciji o strategiji nacionalne varnosti Republike Slovenije iz leta 2010 je v nadaljevanju zapisano, da Slovenija za zagotavljanje notranje varnosti razvija učinkovit, prilagodljiv in odziven varnostni sistem ter omogoča sodelovanje in vključevanje drugih subjektov pri opravljanju zadev in nalog javne varnosti. Notranjo varnost zagotavlja z delovanjem institucij javne varnosti, policije, državnega tožilstva, inšpekcijskih in nadzornih organov, obveščevalno-varnostnih služb, drugih državnih organov, organizacij z javnimi pooblastili, različnih varnostnih služb in organizacij zasebnega prava ter organov lokalne samouprave na temelju njihovega medsebojnega sodelovanja, tako v Republiki Sloveniji kot na mednarodni ravni, saj danes, po Anželjevih besedah, varnosti ne moremo več zagotavljati le na nacionalni ravni (1998, str. 163).

\subsection{Sistem varstva pred naravnimi in drugimi nesrečami}

Kot pravi Grizold, je bila sistemska ureditev varstva pred naravnimi in drugimi nesrečami (VPNDN) v glavnem oblikovana v obdobju 1993-1994 (2005, str. 182). V Resoluciji o strategiji nacionalne varnosti Republike Slovenije iz leta 2010 je zapisano, da je sistem varstva pred naravnimi in drugimi nesrečami namenjen zagotavljanju varstva ljudi, živali, premoženja, kulturne dediščine ter okolja pred naravnimi in drugimi nesrečami oziroma zmanjšanju števila nesreč ter preprečitvi oziroma zmanjšanju žrtev in drugih posledic teh nesreč (kot nesreča se obravnavajo tudi posledice vojne, uporabe orožja ali sredstev za množično uničevanje ter posledice terorističnih napadov in drugih oblik množičnega nasilja).

»Ne glede na to, da je področje varstva pred naravnimi in drugimi nesrečami organizirano kot samostojen sistem, njegovo upravno-strokovno vodenje ostaja $\mathrm{v}$ pristojnosti Ministrstva za obrambo (prek Uprave Republike Slovenije za zaščito in reševanje kot organa $\mathrm{v}$ sestavi), ki med drugim razpolaga tudi $\mathrm{z}$ infrastrukturo, pomembno za delovanje tega podsistema ob nesrečah.« (Grizold, 1999, str. 81)

»Izvajalci nalog dejavnosti zaščite in reševanja so predvsem državni organi, podjetja, zavodi in druge organizacije, ki se v svoji osnovni dejavnosti ukvarjajo z zaščito in reševanjem, ali pa je njihova dejavnost kako drugače pomembna za zaščito in reševanje. Splošne reševalne naloge in dejavnosti izvajajo zlasti operativni sestavi 
gasilske organizacije ter druge organizacije in društva, kot so Rdeči križ in druge humanitarne organizacije, jamarska in gorska reševalna služba, potapljači in drugi ter neposredno državljani v okviru osebne in vzajemne samozaščite.« (Grizold, 1999, str. 82)

\section{GROŽNJE NACIONALNI VARNOSTI}

V znanstveni in strokovni literaturi je izjemno malo dobrih splošnih opredelitev groženj nacionalni varnosti, ki presegajo taksativno naštevanje pojavov, ki te grožnje povzročajo. Kot zapiše Prezelj, je najbolj znana Ullmanova opredelitev groženj nacionalni varnosti, kamor naj bi spadali tisti dogodki ali nizi dogodkov, ki grozijo, da bodo v kratkem času zelo znižali kakovost življenja prebivalcev države ali zožili izbiro političnih odzivov, ki so na voljo državi in zasebnim nevladnim subjektom (posameznikom, skupinam, korporacijam) znotraj države. Na podlagi tega lahko grožnje nacionalni varnosti na splošno opredelimo kot vse družbene ali naravne pojave, ki zmanjšujejo nacionalno varnost oziroma njene definicijske prvine. To se še posebej nanaša na onemogočanje fizičnega obstoja prebivalstva, motenje ali onemogočanje normalnega delovanja temeljnih družbenih in državnih struktur (oziroma infrastruktur), onemogočanje politične suverenosti in preprečevanje razmeroma nemotenega družbenega razvoja (2007, str. 7).

Po Prezljevo je med netradicionalistično pojmovanimi grožnjami varnosti bistveno več nevojaških kot vojaških pojavov. Ti pojavi se večinoma razvrščajo v skupino po področjih, ki jih stroka večkrat imenuje tudi »dimenzija«. V tem smislu sedanja znanost grožnje varnosti obravnava več temeljnih dimenzij ogrožanja nacionalne varnosti, kot so:

- vojaška, v kateri je ključna grožnja oborožen napad na državo;

- gospodarska, v kateri je glavna grožnja izrazito poslabšanje gospodarskih razmer, ne glede na razlog;

- policijsko-kriminalistična, v kateri je glavna grožnja organizirani kriminal;

- ekološka oziroma okoljevarstvena, v kateri je bistvena grožnja onesnaževanje človekovega okolja;

- zaščitno-reševalna, v kateri so glavne grožnje naravne in antropogene nesreče;

- teroristična, v kateri so glavne grožnje teroristične skupine in njihovi teroristični napadi;

- zdravstvena, v kateri sta glavni grožnji pojav in širjenje nalezljivih bolezni;

- informacijska, v kateri so glavne grožnje namerni posegi v delovanje pomembnih nacionalnih informacijskih sistemov;

- obveščevalna, v kateri je glavna grožnja sovražno delovanje obveščevalnih služb drugih držav;

- migracijska, v kateri je glavna grožnja visoka stopnja ilegalnih migracij (2007, str. 8).

Med gospodarsko krizo se je v Republiki Sloveniji pojavila nova sodobna grožnja nacionalni varnosti, in sicer proračunska. Kot bo razvidno v nadaljevanju, so se 
vojaški izdatki v obdobju od leta 2008 skoraj prepolovili, kar pomeni, da je Slovenija prenehala vlagati v »topove«. Zmanjševanje vojaških izdatkov pa kot posledico prinaša manjšo varnost državljanov in okrnjen nacionalni steber obrambe, kar se je pokazalo ob zadnji grožnji nacionalni varnosti - ob migrantski krizi. Na to je v letnem poročilu Ministrstva za obrambo za leto 2015 opozorila že ministrica Andreja Katič, ko je zapisala, da so na zahtevane ravni pripravljenosti pomembno vplivali varčevalni ukrepi, ki so se izvajali predvsem na področjih posodabljanja in vzdrževanja infrastrukture ter voznega parka, zagotavljanja razmer za delo in bivanja pripadnikov ter zagotavljanja osebne opreme. Tako so zmanjševanje finančnih sredstev in varčevalni ukrepi onemogočili načrtovano zagotovitev in vzdrževanje zmogljivosti ter usposabljanje skladno s sodobnimi vojaškostrokovnimi standardi. Dolgoročno gledano bo nadaljevanje zmanjševanja finančnih sredstev močno ogrozilo zagotavljanje zahtevane in potrebne pripravljenosti Slovenske vojske. Ministrica je v letnem poročilu še zapisala, da vojska ni sposobna izpolniti celotnega obsega nalog v krizi, neposredni vojni nevarnosti ali vojni, kar se je izkazalo med migrantsko krizo.

Celo predsednik države Borut Pahor je med krizo ocenil, da bi morala Republika Slovenija zaradi poslabšanja mednarodnih varnostnih razmer in nalog v Natu sprejeti ukrepe za izboljšanje ravni pripravljenosti Slovenske vojske. Po besedah predsednika naj bi bila vojska že tretje leto zapored na najnižji ravni pripravljenosti delovanja. Kot predsednik republike in kot vrhovni poveljnik njenih obrambnih sil je pozval vlado in parlament, vladajoče in opozicijske stranke ter stroko, naj v najkrajšem mogočem času oblikujejo strokovno in politično soglasje o ukrepih za posodobitev celotnega varnostnega sistema države in Slovenske vojske kot njenega obrambnega stebra (Delo, 28. 4. 2016).

Te nove grožnje nacionalni varnosti, ki je nastala zaradi zniževanja javnofinančnih izdatkov za nacionalno varnost, teorije do zdaj ne omenjajo in je tudi ne poznajo, bo pa v prihodnosti velika težava za obrambni steber Republike Slovenije.

Na vzročno povezavo med višino izdatkov za nacionalno varnost in zagotavljanjem varnosti pred grožnjami je v svojem članku v Dnevniku z naslovom Nacionalna varnost: Bodeča žica - preveč ali v resnici premalo? opozoril že dr. Kotnik, ki je zapisal, da so slovenska obveščevalna služba, policija in vojska zaradi večletnega vztrajnega in pretiranega kleščenja njihovih proračunov ter števila zaposlenih kadrovsko tako podhranjene in tehnološko zastarele, da se je bilo treba pri omejevanju prehoda državne meje med migrantsko krizo vrniti k predmodernim žičnim oviram. Avtor poleg tega še zapiše, da je za učinkovito obvladovanje sodobnih varnostnih izzivov zahodnih družb treba vešče kombinirati štiri ključne dejavnike: celovito in jasno migrantsko politiko, zadostno število ustrezno usposobljenih in motiviranih ljudi v nacionalnovarnostnem sistemu (NVS), sodobnejšo varnostno-obrambno tehnologijo ter ustrezne strukturno-organizacijske rešitve v večplastnem nacionalnovarnostnem sistemu, vpetem v mednarodni varnostni sistem. Kotnik v nadaljevanju še zapiše, da je ob vseh zahtevnejših varnostno-obrambnih nalogah 
temeljno šolanje kadrov že preveč skrajšano in poenostavljeno, ob vse bolj skromnih finančnih sredstvih pa sta dodatno izobraževanje in usposabljanje skoraj zamrla (6. 2. 2016).

Kotnik je na problematiko zmanjševanja izdatkov za nacionalno varnost opozoril že konec leta 2014 v članku z naslovom Skrajni čas je za konec naivnega idealiziranja, ko je zapisal, da kljub navidezni normalnosti stanje na področju nacionalne varnosti ni več sprejemljivo, kaj šele, da bi bilo dolgoročno vzdržno. Tveganje za spodrsljaje in sistemske napake večjih razsežnosti se zaradi večletnega zategovanja pasu namreč povečuje eksponentno in samo vprašanje časa je, kdaj se bo Republika Slovenija znašla na točki, ko vse šibkejša človeški in tehnični faktor ne bosta več zmogla preprečiti nesrečnega sosledja dogodkov v kakšni od varnostno kritičnih situacij in se bo ta tudi v Republiki Sloveniji zato razpletla po najslabšem mogočem scenariju (Dnevnik, 20. 12. 2014).

Priprava proračuna na področju politike, označene kot »obramba in zaščita«, je torej z vidika nacionalne varnosti izjemnega pomena, kar je v svojem delu z naslovom Can Poland Defend Itself? zapisal tudi Paszewski. Po njegovem mnenju je tako kot Slovenija tudi Poljska ignorirala vprašanje, kako braniti nacionalno ozemlje in imeti zadostno pripravljene oborožene sile za uspešno obrambo domovine (2016, str. 7). Poleg tega je Poljska, namesto da bi se osredotočila na stalne grožnje, radikalno zmanjševala moč oboroženih sil in postavila vojsko pod civilni nadzor ter s tem izgubila sposobnost braniti svojo nacionalno varnost (2016, str. 6). Slaba pripravljenost poljske vojske na grožnje, ki pretijo državi s severovzhoda (npr. iz Rusije), je po besedah Paszewskega posledica zmanjševanja vojaških izdatkov, za katero je vzrok gospodarska kriza, ki se je začela leta 2008. Čeprav je Poljska razmeroma dobro prešla skozi gospodarsko krizo, se je vlada vseeno odločila, da bo začasno zmanjšala vojaške izdatke, kar je močno vplivalo na pripravljenost njenih oboroženih sil (The Polish Armed Forces - PAF) (2016, str. 9). Poljska vlada je leta 2015 namenila vojaškim izdatkom dva odstotka bruto domačega proizvoda, kar je primerljivo z Republiko Slovenijo (2016, str. 12).

Young pa je v svojem delu z naslovom Impediments to Reform in European PostCommunist Defense Institutions zapisal, da mora biti obrambni proračun zastavljen tako, da omogoča izpolnitev vseh načrtovanih nalog in misij, vendar je iz letnega poročila Ministrstva za obrambo za leto 2015 razvidno, da ni tako. Kot argument Young navaja, da so reforme na obrambnem področju mogoče le z dodatnimi sredstvi za obrambo (2016, str. 6).

\section{PRORAČUN REPUBLIKE SLOVENIJE PO POLITIKAH}

Na spletni strani Ministrstva za finance je zapisano, da je državni proračun pomemben instrument, ki ga ima vlada na voljo pri izvajanju večletne makroekonomske politike, katere cilj je zagotavljanje stabilnih javnih financ in pospeševanje gospodarskega ter družbenega razvoja. Temeljne naloge pri upravljanju proračuna so: uresničitev proračuna $\mathrm{v}$ okvirih in za namene, kot je 
bil sprejet, njegovo pravočasno in gibljivo prilagajanje spremenjenim fiskalnim okoliščinam ter uresničevanje v proračunu zastavljenih družbenih in gospodarskih ciljev (Splošno o proračunu, 2015).

Proračun je temeljni finančni račun države, v katerem se izražajo prednostne naloge in cilji vlade ter uresničuje politika na gospodarskem in socialnem področju. Proračun je tudi stičišče, v katerem se na eni strani zbirajo davki in drugi fiskalni prejemki, na drugi pa financirajo javni izdatki v različnih oblikah (Kranjec, 2003, str. 305).

Stanovnik zapiše, da so odločitve o obsegu državnega proračuna hkratne odločitve o prihodkovni in odhodkovni strani javnih financ. Velikokrat načrtovani prihodki ne dohajajo načrtovanih odhodkov, posledica tega pa je javnofinančni primanjkljaj (fiskalni deficit), ki je v evropskih državah precej bolj pogost kot fiskalni presežek (2002, str. 6).

Pravne podlage za proračunsko financiranje Republike Slovenije so zakon o javnih financah, ustava, ki ureja temeljna načela, in zakon o izvrševanju proračuna, v katerih so zapisane rešitve za izvrševanje letnega proračuna, poleg njih pa še uredba o dokumentih razvojnega načrtovanja in postopkih za pripravo predloga državnega proračuna, ki ureja način priprave razvojnih dokumentov, oblikovanje politik in določitev državnih razvojnih prednostnih nalog, pripravo proračunskega memoranduma in določitev fiskalnega pravila, postopke in dokumente za pripravo državnega proračuna, njegovih sprememb in rebalansa ter drugih, s temi akti povezanih dokumentov.

Skladno z 10. členom Zakona o javnih financah je proračun sestavljen iz splošnega in posebnega dela ter iz načrta razvojnih programov. Pozornost namenimo predvsem posebnemu delu proračuna, ki opredeli vsebino porabe javnofinančnih sredstev v finančnih načrtih posameznih proračunskih uporabnikov oziroma skupin proračunskih uporabnikov ter vključuje odhodke in druge izdatke delovanja, predstavljene po politikah, glavnih programih in podprogramih (Zakon o javnih financah, 10. člen). Politike (v Zakonu o izvrševanju proračuna Republike Slovenije do leta 2010 področja proračunske porabe) so področja, na katerih država deluje in pomenijo zaokrožene celote glavnih programov s skupnimi splošnimi cilji in na katera so, upoštevaje delovna področja neposrednih uporabnikov, razvrščeni odhodki ter izdatki v finančnih načrtih neposrednih uporabnikov.

Kot pravi Fink Hafner, moramo za razumevanje oblikovanja politik, tudi z vidika priprave proračunskih dokumentov, upoštevati politološki pristop analize politik (angl. policy analysis). Analiza politik je lahko opisna in nam pomaga razumeti oblikovanje procesov in izvajanja vladnih politik ter pomaga pri izboljšavah $\mathrm{v}$ procesu oblikovanja, izvajanja in vrednotenja javnih politik. Analiza politik se je v drugi polovici dvajsetega stoletja razvijala zelo dinamično, tako v vsebinskem kot v institucionalnem pogledu. Znanstveno svetovanje politik se je selilo iz zgolj 
državotvornih vladnih resorjev tudi na področja drugih javnih politik. Kultura znanstvenega svetovanja politiki se širi tudi geografsko. ZDA so doslej najbolj razvile analitično raziskovanje, svetovanje in kulturo oblikovanja političnih odločitev na podlagi predhodnih analiz. Ob koncu 20. stoletja se je ta kultura precej razširila tudi v mladih evropskih demokracijah (2002, str. 9-11).

Politike so bile v slovenski proračun uvedene na podlagi slovensko-švedskega projekta twinning, po katerem sta slovensko Ministrstvo za finance in švedski $\mathrm{ESV}^{1}$ pri uveljavljanju programskega pristopa pri načrtovanju državnega proračuna pripravila razvrstitev proračunskih izdatkov po področjih porabe, glavnih programih in podprogramih ${ }^{2}$ (Final Report on the implementation of the EU Twining Project in Slovenia, Public Expenditure Management, including Medium-term programming and budgetary objectives, Performance budgeting and Public procurement, 2015). Tako opredeljena razvrstitev proračunskih izdatkov je bila prvič uporabljena pri pripravi proračuna Republike Slovenije za leto 2001. Politike naj bi bile oblikovane glede na nacionalni interes države, vsaka politika pa naj izpolnjuje cilje, širše zapisane v strateških dokumentih. Da jih doseže, mora izvesti vrsto aktivnosti, ki se združujejo na ravni podprograma. Posledično je torej treba ovrednotiti vložke in izložke, saj se le tako lahko meri uspešnost posamezne politike, da ne postane »mrtev rokav«, ki ne dosega več ciljev. To je mogoče preveriti tudi s postavitvijo kazalnikov, s katerimi se meri uspešnost posamezne politike. Podprogrami se združujejo v programe.

V 2. členu Uredbe o dokumentih razvojnega načrtovanja in postopkih za pripravo predloga državnega proračuna je zapisano, da je nosilec politike ministrstvo ali vladna služba, ki je odgovorna za splošne cilje na ravni politike, in sicer tako, da usklajuje, spremlja in usmerja delovno skupino, ki jo vodi. Ministrstva in vladne službe so odgovorni za doseganje vseh ravni ciljev, skladno s svojimi pristojnostmi in področjem dela. Poleg tega pripravljajo in spremljajo dokumente razvojnega načrtovanja in matrike logičnega okvira ter poročajo o njihovem izvajanju, upoštevajoč postavljeno hierarhijo splošnih in specifičnih ciljev znotraj politike.

Izdatki Republike Slovenije so skladno s pravilnikom o programski klasifikaciji izdatkov državnega proračuna razdeljeni na 24 področij porabe, ta pa naprej na približno 90 glavnih programov in več kot 300 podprogramov. Pri pregledu urejenosti področja nacionalne varnosti ugotavljamo, da so načrtovalci določili dve politiki, in sicer politiko obrambe in zaščite ter politiko notranjih zadev in varnosti. Ob tem moramo upoštevati, da je terminologija do leta 2013 za prvo politiko uporabljala izraz obramba in ukrepi ob izrednih dogodkih. Podlaga za ti proračunski politiki so tako imenovani stebri nacionalne varnosti, ki so opredeljeni v Resoluciji o strategiji nacionalne varnosti Republike Slovenije iz leta 2010. Ker

\footnotetext{
Swedish National Financial Management Authority.

2 Gre za projekt (twinning), v katerem država, ki je že članica EU, s svojimi izkušnjami svetuje državi, ki se vključuje $v$ EU.
} 
je resolucija temeljni razvojno-usmerjevalni dokument na področju nacionalne varnosti, je podlaga za načrtovanje proračuna omenjenih politik. Pomembna je, ker opredeljuje nacionalne interese in nacionalnovarnostne cilje Republike Slovenije, analizira varnostno okolje, vire ogrožanja varnosti in varnostna tveganja države, določa izhodišča politike odzivanja na posamezne varnostne grožnje in tveganja ter določa najširše sistemsko-organizacijske rešitve celovitega delovanja države pri zagotavljanju nacionalne varnosti. V razdelku 6.3 Resolucije o strategiji nacionalne varnosti Republike Slovenije iz leta 2010 z naslovom Upravljanje in vodenje sistema nacionalne varnosti je zakonodajalec določil, da se s sprejemanjem državnega proračuna zagotavljajo materialne možnosti za uresničevanje nacionalnovarnostne politike.

\section{IZDATKI SLOVENSKE VOJSKE IN POLICIJE OD LETA 2008}

Za uresničevanje posameznih dimenzij nacionalnega (varnostnega) interesa so V sodobni državi odgovorna različna ministrstva. V Republiki Sloveniji je bilo delo razdeljeno z Zakonom o organizaciji in delovnem področju ministrstev, ki je veljal od leta 1994 (v obdobju od 1991 do 1994 je veljal Zakon o organizaciji in delovnem področju republiške uprave), leta 2002 ga je nadomestil Zakon o državni upravi.

Prezelj zapiše, da je v Republiki Sloveniji Ministrstvo za obrambo odgovorno za zagotavljanje vojaške in civilne obrambe, poleg tega pa je v njegovi pristojnosti še zagotavljanje varstva pred naravnimi in drugimi nesrečami. Ministrstvo za notranje zadeve opravlja naloge s področja varovanja državne meje, preprečevanja in odkrivanja kaznivih dejanj in prekrškov, vzdrževanja javnega reda in miru, nadzira posest ter nošenje osebnega orožja itn. Naštete so le nekatere temeljne naloge izbranih ministrstev, pri čemer je treba poudariti, da jih ta ministrstva sama nikakor ne morejo opravljati. So le matična ministrstva, ki morajo sodelovati z drugimi ministrstvi pri uresničevanju svojih nalog, torej pripadajočih vidikov nacionalnega varnostnega interesa. Konsenz o prednostnem vrstnem redu varnostnih področij in interesov se na strateški ravni odraža v nacionalnovarnostnih dokumentih in v tem sklopu predvsem v strateških dokumentih s tega področja. Postavljanje prednosti je delno razvidno tudi iz letne razdelitve državnega proračuna med različne porabnike (ministrstva), ki zagotavljajo različne vidike varnosti. Postavljanje prednosti posameznih vidikov nacionalnega varnostnega interesa je po svoje logično, ker so viri za delovanje posameznih varnostnih mehanizmov omejeni. $\mathrm{V}$ tem smislu so posamezni vidiki tega interesa $v$ tekmovalnem odnosu. Sredstva vsake države so namreč omejena, zato je pomembno, kateri instrumenti zagotavljanja varnosti bodo med prvimi na tako imenovani prednostni listi (2002, str. 629).

Ob tem se postavlja vprašanje, ali je bilo v preteklosti med ministrstvi, ki skrbijo za podsisteme nacionalne varnosti, kaj sodelovanja, dopolnjevanja in nadgrajevanja ali zgolj tekmovanje. Gre za zelo zapleteno tematiko, ki jo lahko prikažemo s številkami proračuna. Novejši proračuni Republike Slovenije, od leta 2008 do danes, namreč prikažejo duha tekmovalnosti. 
Leta 2009 je Vlada Republike Slovenije prvič ustanovila delovne skupine ${ }^{3}$, ki so bile zadolžene za pripravo proračuna za leto 2010, že naslednje leto pa je ustanovila nove ${ }^{4}$. Posamezno delovno skupino je vodil minister, pristojen za področje posamezne politike, zadolžen je bil za usklajevanje dela v skupini, tako da so bile naloge njegove skupine opravljene $\mathrm{v}$ rokih. Pristojni minister je zagotavljal tudi razmere za delo skupine. Težava pa nastane, ker delovna skupina za nacionalno varnost, obrambo in zunanje zadeve zastopa tako politiko obrambe in zaščite kot tudi politiko notranjih zadev in varnosti. Vodja delovne skupine je bila skladno s sklepom vlade Katarina Kresal, ministrica za notranje zadeve. Ministrstvo za obrambo je predstavljala ministrica dr. Ljubica Jelušič, dolgoletna predavateljica na Katedri za obramboslovje Fakultete za družbene vede. Iz preglednic 1 in 2 ter z grafa je ob primerjanju izdatkov Slovenske vojske in izdatkov Policije za proračunsko leto 2011 razviden rezultat pogajanj.

\begin{tabular}{|c|c|c|}
\hline \multirow{4}{*}{$\begin{array}{r}\text { Preglednica 1: } \\
\text { Izdatki Slovenske } \\
\text { vojske }{ }^{5} \text { v evrih } \\
\text { od leta } 2008 \text { do } \\
\text { leta } 2015 \\
\text { Vir: zaključni } \\
\text { računi proračunov }\end{array}$} & $\begin{array}{l}\text { PRORAČUNSKI } \\
\text { UPORABNIK/LETO }\end{array}$ & $\begin{array}{l}1914 \text { Generalštab } \\
\text { Slovenske vojske }\end{array}$ \\
\hline & 2008 & 434.575 .966 \\
\hline & 2009 & 443.558 .267 \\
\hline & 2010 & 461.428 .486 \\
\hline \multirow{5}{*}{$\begin{array}{r}\text { Republike } \\
\text { Slovenije - } \\
\text { posebni del } \\
\text { (veljavni } \\
\text { proračun), za leto } \\
2015 \text { rebalans } \\
\text { proračuna - } \\
\text { posebni del. }\end{array}$} & 2011 & 363.966 .094 \\
\hline & 2012 & 302.018 .193 \\
\hline & 2013 & 276.455 .733 \\
\hline & 2014 & 266.008 .596 \\
\hline & 2015 & 260.004 .541 \\
\hline
\end{tabular}

3 Delovne skupine (DS): 1. srednjeročni makroekonomski okvir in fiskalno pravilo, 2. politika spodbujanja podjetništva, konkurenčnosti ter podpora prestrukturiranju nefinančnih in finančnih družb, 3. raziskovalna in tehnološka politika ter informacijska družba, 4. politika trga dela, 5. politika izobraževanja, športa in kulture, 6. prometna politika, prometna infrastruktura in mobilnost, 7. politika kmetijstva, gozdarstva in ribištva, 8. energetska politika, 9. okoljska in prostorska politika, 10. usklajevanje in koordiniranje razvojnega načrtovanja države, 11. politika zdravstvenega varstva in socialne varnosti, 12. politika nacionalne varnosti, obrambe in zunanjih zadev, 13. politika upravnih, pravosodnih in drugih državnih organov.

${ }_{4}$ Nove delovne skupine (NDS): 1. podjetništvo in konkurenčnost, 2. visoko šolstvo, znanost, tehnologija in informacijska družba, 3. trg dela, 4. izobraževanje in šport, 5. kultura, 6. promet in prometna infrastruktura, 7. energetika, 8. kmetijstvo, gozdarstvo, ribištvo in prehrana, 9. okoljska in prostorska politika, 10. socialna varnost, 11. zdravstveno varstvo, 13. nacionalna varnost, obramba in zunanje zadeve, 14. upravljanje sistemov javne uprave in 15. krepitev institucij pravne države, svobode in varnosti.

5 V zaključnem računu proračuna (posebni del) so izdatki prikazani za proračunskega uporabnika Generalštab Slovenske vojske, ki je organ v sestavi Ministrstva za obrambo. Zaradi lažjega razumevanja je v besedilu namesto Generalštab Slovenske vojske uporabljen termin Slovenska vojska. Skladno z 39. členom Zakona o obrambi pa je definicija Generalštaba Slovenske vojske: »Slovensko vojsko sestavljajo Generalštab, kot organ $v$ sestavi ministrstva, ter njemu podrejena poveljstva, enote in zavodi. Generalštab je najvišji vojaški strokovni organ za poveljevanje z vojsko. Opravlja vojaške strokovne naloge, ki se nanašajo na razvoj, načrtovanje, organizacijo, usposabljanje in delovanje Slovenske vojske." 


\begin{tabular}{|c|c|c|}
\hline \multirow{3}{*}{$\begin{array}{r}\text { Preglednica 2: } \\
\text { Izdatki Policije v } \\
\text { evrih od leta } 2008 \\
\text { do leta } 2015 \\
\text { Vir: zaključni } \\
\text { računi proračunov }\end{array}$} & $\begin{array}{l}\text { PRORAČUNSKI } \\
\text { UPORABNIK/LETO }\end{array}$ & 1714 Policija \\
\hline & 2008 & 312.214 .199 \\
\hline & 2009 & 336.561 .035 \\
\hline \multirow{6}{*}{$\begin{array}{r}\text { Republike } \\
\text { Slovenije - } \\
\text { posebni del } \\
\text { (veljavni } \\
\text { proračun), za leto } \\
2015 \text { rebalans } \\
\text { proračuna - } \\
\text { posebni del. }\end{array}$} & 2010 & 336.227 .163 \\
\hline & 2011 & 324.653 .699 \\
\hline & 2012 & 294.082 .226 \\
\hline & 2013 & 297.998.551 \\
\hline & 2014 & 292.907 .995 \\
\hline & 2015 & 278.696 .543 \\
\hline
\end{tabular}

Graf 1: Primerjava izdatkov Slovenske vojske in Policije od leta 2008 do leta 2015

Vir: zaključni računi proračunov

Republike

Slovenije posebni del (veljavni proračun), za leto

2015 rebalans proračuna posebni del, avtoričin prikaz.
IZDATKI V EUR

500.000 .000

450.000 .000

400.000 .000

350.000 .000

300.000 .000

250.000 .000

200.000 .000

150.000 .000

100.000 .000

50.000 .000

0

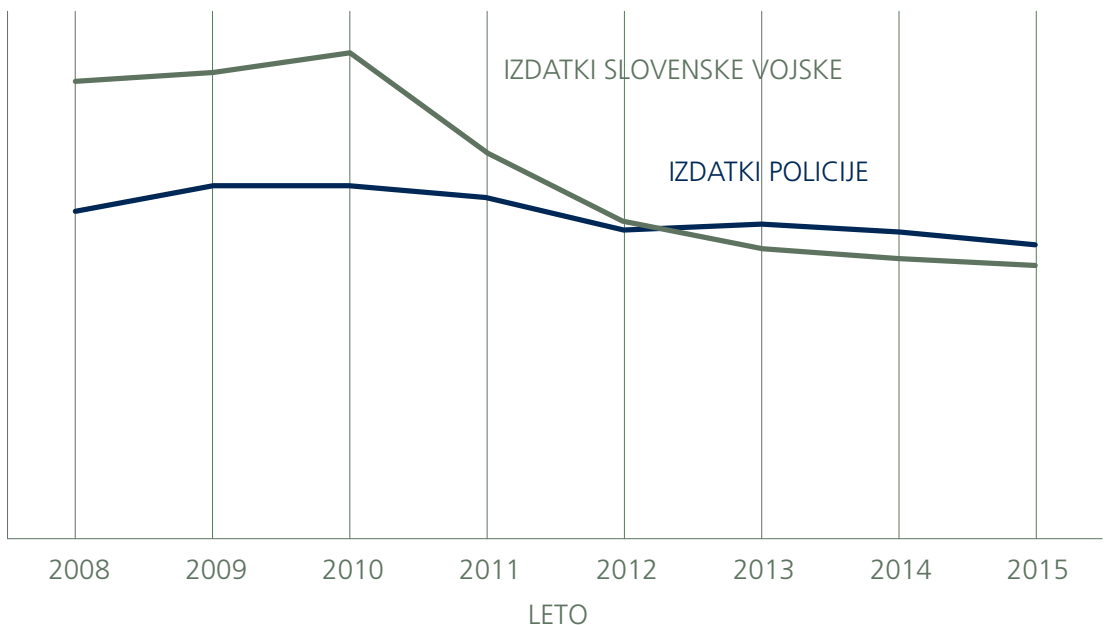

Iz preglednic in grafa je razvidno, da so se izdatki Slovenske vojske v obdobju od leta 2008 do leta 2015 skoraj prepolovili, medtem ko so izdatki Policije leta 2014 že skoraj dosegli izdatke iz leta 2008. Izdatki Slovenske vojske so se vse od leta 2011 zelo zmanjševali, leta 2013 pa so bili izdatki Policije že višji.

$\mathrm{Na}$ podlagi teh podatkov lahko ugotovimo, da je imelo Ministrstvo za notranje zadeve v delovni skupini bistveno boljše izhodišče pri pogajanjih za višino sredstev kot Ministrstvo za obrambo. V izjemno težki finančni situaciji (gospodarski krizi, ki je začela na proračun vplivati leta 2010 za leto 2011), v kateri se je znašla Slovenija, 
je prišlo do izraza zagovarjanje potreb Ministrstva za notranje zadeve na račun obrambnega sistema. Ministrica za obrambo je ob predstavitvi proračunov za leti 2010 in 2011 pred pristojnim odborom Državnega zbora 14. oktobra 2009 poudarila, da postopno zmanjševanje sredstev za obrambo zaustavlja načrtovani razvoj na področju obrambe in civilne zaščite, reševanja in prve pomoči, zmanjšuje načrtovani kadrovski obseg vojske, nekatere stvari pa premika v prihodnost (Zmanjševanje sredstev zaustavlja načrtovani razvoj obrambnega sistema, 2015). Ob rebalansu proračuna junija 2010, s katerim so se sredstva za plače in druge izdatke v Slovenski vojski zmanjšala za deset odstotkov, je na seji odbora za obrambo ministrica za obrambo ponovno opozorila, da bo tudi manj denarja za nakup vojaške opreme, poslanci pa so opozorili zlasti na zmanjšanje sredstev za sistem varstva pred naravnimi nesrečami.

Poleg sprememb pri pripravi proračuna leta 2009 je na izdatke Slovenske vojske vplivala tudi gospodarska kriza, ko so se odločevalci zavestno odločili oslabiti izdatke za nacionalnovarnostni sistem, s posebnim poudarkom na obrambi. Zato so se začeli zmanjševati izdatki za vojsko, kar pomeni, da je Republika Slovenija za »topove« začela namenjati čedalje manj denarja. Tako smo prišli do nove, v teorijah še ne omenjene sodobne grožnje, ki jo lahko poimenujemo proračunska grožnja. Proračunska grožnja je posledica dveh dejavnikov: spremembe v postopku priprave proračuna iz leta 2009 in gospodarske krize. Oba sta se pojavila v istem obdobju in skupaj povzročila alarmantne razmere v stebru obrambe.

Sklep Vsem dosedanjim vojaškim in nevojaškim grožnjam nacionalni varnosti lahko na podlagi ugotovitev dodamo novo grožnjo, ki je aktualna v vseh državah, ki so doživele ekonomsko krizo, zaradi katere so zniževale izdatke za obrambo. Gre za proračunsko grožnjo, ki je nastala zaradi zniževanja javnofinančnih izdatkov za nacionalno varnost in je teorije do zdaj ne omenjajo oziroma ne poznajo. Gre seveda za sodobno grožnjo, ki bi jo države s pravočasnimi ukrepi in vedenjem o pomembnosti povezave med ekonomijo in obrambo lahko vsaj omejile, če je že ne bi mogle preprečiti.

V Republiki Sloveniji se je ta grožnja kot zelo nevarna pokazala že ob migrantski krizi. Zaradi proračunske grožnje trpi tudi suverenost nacionalne varnosti, saj Slovenska vojska in Policija ne moreta več uresničevati zavez iz Resolucije o strategiji nacionalne varnosti Republike Slovenije iz leta 2010, na kar že nekaj časa opozarjata tako Ministrstvo za obrambo kot tudi predsednik države kot vrhovni poveljnik obrambnih sil.

Na nizke standarde v Slovenski vojski in na neizpolnjevanje zavez Natu je ves čas migrantske krize opozarjal tudi Damir Črnčec. V eni izmed izjav je dejal: »Dober nacionalnovarnostni sistem je najprej $\mathrm{v}$ interesu lastne države in potem države kot enakopravne članice zveze Nato ali Evropske unije. To zelo dobro razumejo v Črni gori, za Slovenijo pa nisem več prepričan! Kajti če bi razumeli, se policija in vojska ne bi ukvarjali s premalo sredstvi za svoje delovanje.« (2016, str. 283) 
Ugotovimo lahko, da so teoretiki in praktiki povezavi med fiskalno ekonomijo in obrambo namenjali premalo pozornosti, saj bi v nasprotnem primeru z analizo politik lahko ugotovili, da z zniževanjem javnofinančnih izdatkov ustvarjajo novo grožnjo nacionalni varnosti - proračunsko grožnjo.

De France je zapisal, da raziskovalci že uvrščajo našo državo v tako imenovano kategorijo južnih evropskih držav, za katere je značilno zmanjševanje izdatkov za obrambo. Nasprotni pol so severne in vzhodne evropske države, ki ne glede na svoj status, nevtralnost ali članstvo v Natu, načrtno povečujejo delež sredstev za obrambo (2015).

\section{Literatura}

1. Anželj, D., 1998. Slovenska policija v luči evropskih integracij. V D. Zajc (ur.), Evropeizacija slovenske politike. Ljubljana, Slovensko politološko društvo, 1998, str. 163-177.

2. Anžič, A., 1997. Varnostni sistem Republike Slovenije. Uradni list Republike Slovenije, Ljubljana, 1997.

3. Brezovšek, M., Črnčec, D., 2007. Demokratična uprava in tajnost podatkov. Fakulteta za družbene vede, Ljubljana.

4. Črnčec, D., 2016. Kresovi. Mohorjeva družba, Ljubljana.

5. Defence budgets in Europe: Downturn or u-turn? by Olivier De France, European Union Institute for Security Studies, maj 2015 URL=» http://www.iss.europa.eu/uploads/media/ Brief_12_Defence_spending_in_Europe.pdf«.31.3. 2016.

6. Final Report on the implementation of the EU Twining Project in Slovenia, »Public Expenditure Management, including Medium-term programming and budgetary objectives, Performance budgeting and Public procurement, refenece no. SL99/IB/Fi/03, 31. 8. 2015.

7. Fink-Hafner, D., 2002. Analiza politik. Fakulteta za družbene vede, Ljubljana.

8. Grizold, A., 1998. Institucionalizacija zagotavljanja mednarodne varnosti. V: A. Grizold (ur.), Perspektive sodobne varnosti. Fakulteta za družbene vede, Ljubljana.

9. Grizold, A., 1999. Evropska varnost. Fakulteta za družbene vede, Ljubljana.

10. Grizold, A., 1999. Obrambni sistem Republike Slovenije. Ministrstvo za notranje zadeve, Ljubljana

11. Grizold, A., 2005. Slovenija v spremenjenem varnostnem okolju. Fakulteta za družbene vede, Ljubljana

12. Kotnik, I., 2016. Nacionalna varnost: Bodeča žica-preveč ali v resnici premalo? Dnevnik, 6. 2. 2016.

13. Kotnik, I., 2014. Skrajni čas je za konec naivnega idealiziranja. Dnevnik, 20. 12. 2014.

14. Letno poročilo Ministrstva za obrambo za leto 2014. http://www.mo.gov.si/fileadmin/ mo.gov.si/pageuploads/pdf/javne_objave/2015/LP_MO_2014.pdf, 15. 10. 2015.

15. Letno poročilo Ministrstva za obrambo za leto 2015. http://www.mo.gov.si/fileadmin/ mo.gov.si/pageuploads/pdf/ministrstvo/LP_MO_2015.pdf, 15. 10. 2015.

16. Malešič, M., 2012. Teoretske paradigme sodobne varnosti in okolje kot varnostno vprašanje. Teorija in praksa, 2/2012, str. 264-282.

17. Pahor, B., 2016. Nujno je treba izboljšati varnostni sistem. http://www.delo.si/novice/ politika/pahor-neizogibno-je-treba-izboljsati-varnostni-sistem.html, 1. 10. 2016.

18. Paszewski, T., 2016. Can Poland Defend Itself? Survival, številka 2, april-maj 2016, str. $117-134$. 
19. Pravilnik o programski klasifikaciji izdatkov državnega proračuna. Uradni list RS, št. 112/03, 56/05, 141/06 in 58/09.

20. Prezelj, I., 2002. Kompleksno ogrožanje varnosti in nastajanje kompleksnih kriz. VM. Malešič (ur.), Nacionalna in mednarodna varnost. Ljubljana, Fakulteta za družbene vede, 2007, str. 59-76.

21. Prezelj, I., 2002. Konceptualizacija nacionalnih varnostnih interesov. Teorija in praksa. 4/2002, str. 621-637. http://dk.fdv.uni-lj.si/tip/tip20024Prezelj.PDF, 15. 10. 2015.

22. Prezelj, I., 2007. Uvod v ocenjevanje ogrožanja nacionalne varnosti. V: I. Prezelj (ur.), Model celovitega ocenjevanja ogrožanja nacionalne varnosti Republike Slovenije. Ministrstvo za obrambo Republike Slovenije, Ljubljana, 2007, str. 7-26.

23. Prva obravnava predloga Zakona o javnih financah. http://www.dz-rs.si/wps/portal/ Home/deloDZ/zakonodaja/izbranZakonAkt? uid $=$ C12563A400339077C1256735004A93F $8 \& d b=k o n \_z a k \&$ mandat $=I I \&$ tip $=$ doc, 20. 12. 2015.

24. Resolucija o strategiji nacionalne varnosti Republike Slovenije iz leta 2010. Uradni list RS, št. 27/10.

25. Rizman, R., 1998. Ali sta nacionalna suverenost in identiteta v zatonu? V D. Zajc (ur.), Evropeizacija slovenske politike. Ljubljana, Slovensko politološko društvo, 1998, str. 17-27.

26. Splošno o proračunu. http://www.mf.gov.si/si/delovna_podrocja/proracun/splosno_o_ proracunu/, 20. 12. 2015.

27. Sprejeti proračuni Republike Slovenije. http://www.mf.gov.si/si/delovna_podrocjal proracun/sprejeti_proracun/, 15. 10. 2015.

28. Stanovnik, T., 2002. Javne finance. Ekonomska fakulteta, Ljubljana.

29. Uredba o dokumentih razvojnega načrtovanja in postopkih za pripravo predloga državnega proračuna. Uradni list RS, št. 79/99, 124/00, 79/01, 30/02, 56/02 - ZJU, 110/02 - ZDT-B, 127/06 - ZJZP in 14/07 - ZSPDPO, 109/08, 49/09 in 38/10 - ZUKN.

30. Young, T.D., Impediments to Reform in European Post-Communist Defense Institutions. http://www.tandfonline.com/doi/full/10.1080/10758216.2016.1220256, 20. 11. 2016.

31. Zaključni računi Republike Slovenije. Dostopno na:http://www.mf.gov.si/si/delovna_ podrocja/proracun/zakljucni_racun/, 15. 10. 2015.

32. Zakon o javnih financah. Uradni list RS, št. 11/11 - uradno prečiščeno besedilo, 14/13popr., 101/13 in 55/15-ZFisP.

33. Zmanjševanje sredstev zaustavlja načrtovani razvoj obrambnega sistema. https://www.sta. si/1437257/jelusiceva-zmanjsevanje-sredstev-zaustavlja-nacrtovani-razvoj-obrambnegasistema, 10. 10. 2015.

34. Žnidarič, B., 2006. Teoretična izhodišča sodobne varnostne paradigme. Delo in varnost, 51/2006/5, str. 53-56. 